\title{
A jelenkori nyelvjárási adatok történeti dialektológiai forrásértéke*
}

1. A nyelvjárástörténet szinte axiómaként kezeli azt a megállapítást, amely szerint a mai nyelvjárásokban ${ }^{1}$ - a nyelvjárások eltérő ütemü és irányú történeti változása révén - egymás mellett adatolhatók bizonyos nyelvi jelenségek különbözö változási fázisai (vö. ERDÉLYI 1905: 201; BÁRCZI 1958: 14, 1964: 11; BENKÖ 1967: 56, 1967/2003: 156, 1990: 11; IMRE 1971: 135; JuHÁSZ 1997: 7, 2002: 152, 2007: 134; KISS J. 1981: 15). Ebből pedig az is kétségtelenül következik, hogy a mai nyelvjárások fontos forrását jelenthetik a történeti nyelvjáráskutatásnak. Ezzel, illetve a nagy mennyiségü jól lokalizálható történeti adat korabeli hiányával, azok értékelésének nehézségeivel magyarázható az, hogy a 20. század második felétől kezdődően (1. ehhez IMRE 1971: 134) a magyar nyelvjárástörténeti, nyelvtörténeti munkákban a mai nyelvjárások jellemzőire igen nagy mértékben építettek a kutatók akkor, amikor a korábbi évszázadok hangtani állapotának területi különbségeit igyekeztek leírni.

Az elmúlt évtizedek forrásfeltárásainak következtében azonban napjainkban viszonylag nagy mennyiségü lokalizált történeti adat áll a rendelkezésünkre, ami a korai évszázadok nyelvjárási viszonyainak rekonstrukcióját, s egyúttal az ún. retrospektív elemzéseknek a felülvizsgálatát is lehetővé teszi. Az ilyen típusú felülvizsgálatoknak ugyanakkor az is a hozadékai közé tartozhat, hogy adott esetben a történeti és a jelenkori adatok vallomása között feszülő ellentmondást feloldják, azokra magyarázatul szolgáljanak. Ehhez viszont a történeti adatok sokszempontú elemzése szükséges, amelynek során bizonyos módszertani problémáknak (mint például az oklevélírói gyakorlat normáinak vagy az oklevelek bizonyos mértékig véletlenszerü fennmaradásának) a figyelembevétele elengedhetetlen az adatok forrásértékének számbavételekor.

A történeti és a jelenkori adatok értékelése és bizonyító erejének szembesítése során másfelöl a jelenkori adatok felhasználásával kapcsolatban is felmerülnek bizonyos módszertani akadályok. Így például az egyes hangtani szembenállások közötti változásviszonyok ${ }^{2}$ vagy más oldalról a településtörténeti, migrációs folyamatok

* A tanulmány az MTA Prémium Posztdoktori Kutatóprogram keretében készült (befogadó intézmény: Debreceni Egyetem).

${ }^{1}$ Jelenkori nyelvjárási adatokként elsősorban azokat az adatokat alkalmazom, amelyek lejegyzése az 1950-es-1960-as években történt A magyar nyelvjárások atlaszának (MNyA.) gyüjtömunkálatai alatt. Néhány, a tanulmányban felhasznált példa ugyanakkor ennél korábbi is lehet (1. pl. a HORGER ANTAL által említett adatokat).

${ }^{2} \mathrm{Az} \ddot{e} \sim \ddot{o}$ szembenállás például a nyíltabbá válás következtében korábbi $i \sim \ddot{u}$ szembenállás folytatása is lehet. A legerősebben $\ddot{o}$-ző területeken pedig bizonyos változási folyamatok következtében gyakran nem $\ddot{o}$-zö nyelvjárási adatokat találunk. Az $\ddot{o}>\ddot{u}$ zártabbá válás eredményei lehetnek például az alábbi elemek bizonyos nyelvjárási formái: egres (egrüst, D37, MNyA. 107), énekel (énękül, D12, énęü̈l, D15, èinekü, D22, éinekü, D25, énekül, D25, ëinekül, D27, énekül, D28, MNyA. 879), lepedö (lepüdö, F15, F22, F23, MNyA. 218). Még gyakrabban bukkanunk olyan formákra, amelyek az l, $j$

Magyar Nyelv 117. 2021: 23-37. DOI: https://doi.org/10.18349/MagyarNyelv.2021.1.23 
következtében a mai magyar nyelvjárásokban fellelhető nyelvi jelenségek csak megszorításokkal használhatók fel egy-egy ómagyar kori nyelvjárási sajátosság lokalizálásában. Sok tekintetben azonban a mai nyelvjárási adatok reálisan is támpontot nyújthatnak bizonyos nyelvjárástörténeti megfigyelésekhez. A következőkben azt igyekszem bemutatni, hogy melyek azok a hangtani jelenségek, amelyek vizsgálatában a jelenkori nyelvjárási adatok hiteles forrását jelenthetik a nyelvjárástörténetnek. Ezt követően pedig azt a konkrét problémát járom körül, hogy miért merülhetnek fel kételyek bennünk akkor, ha az ómagyar kori $\ddot{u}$-zés gócpontjának meghatározásához a jelenkori ö-ző nyelvjárási adatokra támaszkodunk.

2. A jelenkori nyelvjárási anyag történeti dialektológiai felhasználására a szakirodalom bőséggel szolgáltat példákat.

2.1. A mai nyelvjárásokban fellelhető adatok - minthogy a jelenkori nyelvjárásokban a nyelvi változások egyes állomásait érhetjük tetten - nagy biztonsággal hívhatók segítségül például akkor, amikor az adott változás lezajlásának fázisait kívánjuk rekonstruálni (vö. BENKÖ 1967/2003: 156-157, 1967: 63, 1990: 18). BÁRCZI GÉZA például az $i>\ddot{u}$ labializáció szó vége felöli terjedésével kapcsolatban jegyzi meg, hogy azt a nyelvtörténeti adatokon túl egyes mai nyelvjárásokbeli gyengébb $\ddot{o}$-zés is mutatja. Az anyanyelvjárástól elszigetelődő, s ezért egy korábbi fejlődési fokozaton megmaradó, a csak a hangsúlytalan szótagban labializáló nyelvjárásaink közé a szlavóniai vagy az Abaúj megyei Füzéri járási nyelvváltozatot sorolja (BÁRCZI 1958: 49; IMRE 1971: 135).

2.2. A jelenkori nyelvjárási adatok minden bizonnyal fogódzóként szolgálhatnak az olyan esetekben is, amikor az egyes nyelvjárástörténeti jelenségek egymáshoz viszonyított kronológiai sajátosságait próbáljuk meg felfejteni.

HORGER ANTAL szerint például a jelenkori nyelvjárási adatok Somogy megyében azt igazolják, hogy ezen a területen az ö-zés régebbi jelenség, mint az $l$ kiesése. Azokban a szavakban ugyanis, amelyekben azonszótagú $l$ következett az $\ddot{o}$-re, a korábbi $\ddot{o}$ helyén ma már $̋$ van a vizsgált régióban (1933: 101). Ez pedig csak akkor lehetséges, ha az $\ddot{u}>\ddot{o}, \ddot{e}>\ddot{o}$ változás hamarabb végbement, mint az $l$ kiesése.

A székely nyelvjárásterület $\ddot{o}$-zésével kapcsolatban szintén HORGER állapítja meg, hogy az erősebb és a gyengébb fokú $\ddot{o}$-zés területén is az azonszótagú $l, r$, $j$ hangok elött megnyúlt az $\ddot{o}$ (pl. énekölnek, embör, székőj), ami azt jelzi, hogy az $l, r, j$ nyújtó hatása későbbi jelenség, mint az $\ddot{o}$-zés (1933: 102). Az ö-ző terület legészakibb csúcsán (Zetelaka, Firtosváralja és Hodgya környékén) viszont embér, éneké (< énekél), széké (< székéj), fébiztat, féső típusú alakokat találunk.

hangok pótlónyúlásos kiesése következtében jöttek létre, pl. tengely (tengő, D12, D21, D28, F3, F6, F10, F15, F22, F23, G3, K1, K12, N8, tengö, B33, D28, tengő, B33, D29, tengő, B35, tengò̀, D12,

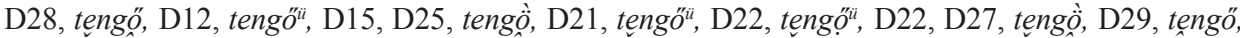
F3, MNyA. 156), zsindely (séndö, B33, D28, séndöï, D22, séndô, D28, séndô,, D28, séndő, D29,

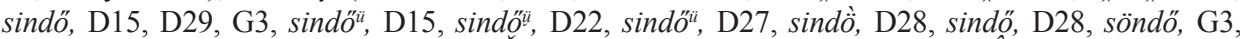
söndö, G3, zsindö, G3, MNyA. 202), gerendely (göröndò̀, B33, D22, göröndö, B35, D12, D15, D21, F3, F6, F10, F15, F22, F23, K1, N8, göröndö, D12, D28, D29, G3, göröndö̈̈, D12, D22, D25, D27, göröndö̈, D22, MNyA. 124), énekel (énökö, B33, B35, énekö, B35, D21, énekö, D28, énęö, D29, énêkö, F゙6, inökö, G3, MNyA. 879). 
Mivel pedig az $\mathscr{O}>e$ é változásnak nincs nyoma a vidéken, HoRGER szerint a jelenségnek az a magyarázata, hogy a terület eredetileg $\ddot{e}$-ző volt, s az $\ddot{o}$-zés csak akkor terjedt át ide, amikor az azonszótagú $l, r, j$ már megnyújtotta az előtte álló $\ddot{e}$-t, így ezekben nem alakult ki az $\ddot{o}$-ző forma (1933: 102). Hasonlóképpen magyarázhatjuk a moldvai régióban és a Dunántúlon (a bukovinai székelyek dél-dunántúli letelepedésével létrejött nyelvjárásszigeteken) elterjedt féd 'föld', pl. féd (Gajcsána-Dtúl), féden (Lészped), fédën (Moldva-Dtúl), fédën (Lészped-Dtúl), fédhéz [= földhöz] (Lészped), fédnek (Gálbény), fédön (Pacsa) (ÚMTsz.) és a (szintén nyelvjárássziget jellegü) kupuszinai végy 'völgy' (SILLING 2007: 374) formákat is. Hozzá kell tennünk azonban, hogy a kupuszinai végy 'völgy' kialakulásához az is hozzájárulhatott, hogy a település nyelvváltozatából „még a közelmúltban is hiányoztak a labiális palatális magánhangzók" (FODOR 2001: 330), amit jól mutatnak az olyan formák is, mint pl. iszëg 'üszök', bikkëny 'bükköny', këles 'köles', tërëktëk 'töröktök' stb. (Ju4, MNyA. 13, 20, 64).

2.3. A mai nyelvjárások adatai olykor még korai ómagyar kori helyesírási kérdésekben is támpontul szolgálhatnak. Az $i \sim \ddot{u}$ szembenállás körébe vonható példák megítélésében például az $i u, y w, y u$, (ritkábban) $i v, i w, y v$ betükapcsolatot tartalmazó korai ómagyar adatok okoznak problémát, e kapcsolatok hangértéke ugyanis $\ddot{u}$, $\ddot{u}$ és $\underline{i u ̈}$ egyaránt lehet, például: kis 1331>1358: Kyusida (KMHsz. 1: 157), 1327: Kywssorlow, Kyussorlov (Gy. 3: 243), 1318: Kywstopolchan (KMHsz. 1: 157), 1322/323: Kyus Ermen (Gy. 3: 481), 1314: Kyusfolud (KMHsz. 1: 156), 1329: Kyuskereskyn (Gy. 3: 206), 1318: Kywsytua (KMHsz. 1: 158), 1320: Kyuseskuleu (Gy. 2: 68). A diftongusra ebben az esetben azért nem gondolhatunk, mert a kis lexéma később sem hangzott hosszú magánhangzóval (vö. ÚMTsz. 3: 359360), ami azért fontos körülmény, mert az iü diftongus hosszú $i$, ü magánhangzóvá alakult tovább. A kis kapcsán tehát nagy bizonyossággal tehetjük le a voksunkat a megfelelö betükapcsolat $\ddot{u}$ hangértéke mellett.

Bár a kérdés tisztázásában nem nyújt segítséget, mégis fontos hozzátennünk azt is mindehhez, hogy KNIEZSA ISTVÁN szerint az $i u, y u$ betükapcsolatok $\ddot{u}$, $u$ hangértékben való használata a 13. század második felében nem hazai fejlödés eredménye, hanem a középfelnémetből való írásszokás. Az említett betűkapcsolatok megjelenése tehát nem annak köszönhetö, hogy az iü diftongus $\ddot{u}$ hanggá alakult. Ekkor ugyanis az a helyzet állna fenn, mint a rövid ö jelölésére használatos eu, ew esetében: az $O$ tudniillik a korábbi eü diftongusból alakult, aminek eu, ew volt a jelölése, s később a hosszú $o ̋$ eu, ew jelét a rövid $\ddot{o}$ hangra is alkalmazni kezdték (KNIEZSA 1952: 74). KNIEZSA úgy gondolja, hogy ha az iu, yu grafémakombinációk $\ddot{u}, u$ hangértékben való elöfordulása magyar fejlemény lenne, akkor az azokat tartalmazó szavakban (pl. füz, tö stb.) korábban is jelölte volna a hosszú $u$-t $i u$, illetve $y u$. Ezeket a betükapcsolatokat azonban az $\ddot{u}$ hang jelölésére ugyanakkor kezdték használni, mint a rövid $\ddot{u}$ hang lejegyzésére (KNIEZSA 1952: 74).

2.4. A jelenkori nyelvjárási adatok vallomása alapján a változások területi terjedésének a határaira is következtethetünk, bár településtörténeti változások ezeknek a határoknak a kisebb-nagyobb módosulását kétségkívül előidézhették.

Így például az $l$-ezés, illetve a $j$-zés terjedésének határait jelzik a mai, archaikus $l y$-ező adatok a palóc területeken (vö. lyuk, MNyA. 939), vagy a palatális- 
veláris és labiális-illabiális köznyelvi toldalékok izoglosszáját mutatják a nem illeszkedett kapável, Ferihö, Feriho adatok az Örségi és hetési nyelvatlaszban (ÖHA. 104, 105; BENKÖ 1957: 22). A labiális $a$-zás terjedésének határait mutathatják egyes feltételezések szerint a mai palóc, csángó és szlavóniai $\dot{a}-\mathrm{k}$ is, bizonyos elképzelések szerint ugyanis az illabiális $\dot{a}$-k korábban az egész nyelvterületen jellemzőek voltak, s csak később szorultak vissza a labiális $a$-k terjedésének következtében (BENKÖ 1957: 74; de 1. BÁRCZI 1958: 58; vö. E. ABAFFY 2003: 325-326; JUHÁSZ 2018: 329).

2.5. BÁRCZI GÉZA és E. ABAFFY ERZSÉBET az $i>\ddot{u}$ labializáció gócpontjának meghatározásában is a mai nyelvjárások vallomására támaszkodott. Ezzel összefüggésben ugyanis megjegyzik, hogy az ü-zés következményeképpen kialakuló legerősebb $\ddot{o}$-ző tendencia ma Baranya és Somogy megyében, illetve Szeged környékén tapasztalható (BÁRCZI 1967/2002: 156; E. ABAFFY 2003: 324). Ez a megállapítás azonban megfigyeléseim szerint a jelenleg rendelkezésünkre álló történeti adatokkal nem hozható összhangba (1. ehhez BÁBA 2019), ezért érdemes a kérdést alaposabban is megvizsgálni.

3. Az $i>\ddot{u}$ labializáció gócpontjának meghatározásakor kutatóink tehát fontos fogódzóként használják az ö-zésnek a jelenkori nyelvjárásokban tapasztalható sajátosságait. Ehhez azt az - ismereteim szerint empirikus adatokkal nem igazolt nézetet veszik alapul, hogy az $\ddot{u}>\ddot{o}$ nyíltabbá válásnak az $\ddot{o}$-zés kialakulásában olyan nagy szerepe lehetett, hogy talán ,,a régi magyar $\ddot{u}$-ző nyelvjárás fejlődhetett át ö-zővé" (PÉTER 1951: 120; vö. még HORGER 1933: 103-104).

A korábbi írások azt is hangsúlyozzák ugyanakkor, hogy az ö-zés (több más nyelvjárási hangtani jelenséghez hasonlóan) különböző hangváltozási folyamatok eredményeképpen alakult ki. Az ö-ző alakok tehát a nyíltabbá válás (pl. szüm > szöm, tengür > tengör) mellett létrejöhettek például korábbi ë labializációjával (pl. për $>$ pör, fülë $>$ fülö), az $l$ zárhang előtti vokalizációjának asszociációs hatásaként $^{3}(\mathrm{pl}$. vëlgy $>$ vëügy $>$ vö̈̈gy $>$ vögy $>$ völgy), valamint például diftongusból lett hosszú ő rövidülésével (pl. tëüt > töt 'tett' > tött) (HORGER 1933: 101; PÉTER 1951: 120, 121; BENKŐ 1957: 16; SZABÓ 1996; E. ABAFFY 2003: 326). Az eddigi feltételezések szerint ezek a hangváltozások többnyire más-más időkben és területileg is elkülönülve következtek be, ami persze nem zárja ki azt, hogy a változási tendenciák terjedésük következtében érintkezve egymás hatását is felerősítették. Az a hipotézis tehát, hogy az ö-zés kialakulásában a nyíltabbá válásnak lehetett a legerőteljesebb szerepe (E. ABAFFY 2003:330), még akkor is bizonyításra szorul, ha elfogadjuk, hogy ezek közül a folyamatok közül talán a nyíltabbá válási tendencia indult meg a leghamarabb, $\mathrm{s}$ a nyíltabbá válás meglehetősen általános, minden más magánhangzó-változásnál erősebb tendencia lehetett (lásd ehhez LAZICZIUS 1936: 25). Az $\ddot{u}$ hang ugyanakkor - mivel az ösmagyar korban még valószínüleg nem volt meg minden nyelvjárásban (E. ABAFFY 2003: 124) - nem lehetett túl gyakori

\footnotetext{
${ }^{3}$ Asszociációs, függő - más szóval kombinatorikus (vö. KISS 2003: 55) - hangváltozásoknak nevezzük az olyan módosulásokat, amelyek esetében a hangok egymásra hatása következtében jön létre a változás (BÁRCZI 1967/2002: 125-128; E. ABAFFY 2003: 110; GERSTNER 2018: 104).
} 
az ómagyar korban, ${ }^{4}$ még azzal együtt sem, hogy az $\ddot{u}$-k gyakoriságát a korban az $i>\ddot{u}$ labializáció megnövelte. Az ë ezzel szemben gyakori hangnak számíthatott: az $e, \ddot{e}$ hangok arányszámához képest más hangok, például az $a, \dot{a}$ gyakorisága BÁRCZI szerint a korban messze alulmarad (1975: 143). S minthogy a labializáció is általános, a magánhangzórendszert (a nyíltabbá váláshoz hasonlóan) egészében érintő tendenciaként müködhetett, feltételezhetjük, hogy az $\ddot{e}>\ddot{o}$ változás is gyakori folyamatként jelentkezett.

4. Annak eldöntésében, hogy az $i>\ddot{u}$ labializáció gócpontjának kijelölésében mennyire lehet mérvadó a jelenkori nyelvjárások $\ddot{o}$-zése, az $\ddot{u}>\ddot{o}$ nyíltabbá válás területi sajátosságai nemigen jöhetnek a segítségünkre. Az $\ddot{O}$ és $\ddot{u}$ hangok sokáig tartó $u$-s és $v$-s jelölése miatt (vö. BÁRCZI 1958: 46) ugyanis nem tudjuk meghatározni a változás kiindulópontját. BÁRCZI GÉZA szerint a nyíltabbá válási tendenciák közül legfeljebb az $i>\ddot{e}$ kiindulási gócáról lehetnek feltevéseink. BÁRCZI ehelyütt nem fejti ki ugyan, de valószínüleg a törzsnévi adatok meglehetősen ingatag vallomására támaszkodik ennek az óvatos megjegyzésnek a megfogalmazásában is. Az $i>\ddot{u}$ és az $i>\ddot{e}$ változások gócáról ugyanis több helyen a Kürtgyarmat és a Megyer törzsnév hangtani sajátosságait és ezeknek a törzseknek a feltételezett letelepedési helyét veszi alapul (vö. 1958: 40, 1975: 131). Véleménye szerint az egyes nyíltabbá válási tendenciák párhuzamossága sem igen valószínü (BÁRCZI 1958: 47), így ezek figyelembevétele sem vezethet eredményre.

Az $\ddot{o}$ hang jelölésére kezdetben az $u, v$ és ritkábban $o$ grafémát alkalmazták. KOROMPAY KLÁRA megfogalmazása szerint az $\ddot{o}$ hangnak „leggyakrabban az $u$ betü a jele, pontosabban ilyen írásmód hátterében kereshetjük kellő óvatossággal” (2003: 288), pl. HB.: vermut [ßermöt], ÓMS.: urume(m)tuul [örömemtül]. Minthogy azonban az $u$ graféma az $\ddot{u}$ hangot is jelölhette (pl. HB. zumtuchel

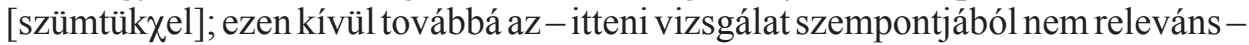
$u$, $o$, $u$ és $\beta$ hangokat is, KNIEZSA 1952: 15, 19, 79, 84, 85; KOROMPAY 2003: 291), az $\ddot{u}>\ddot{o}$ nyíltabbá válási tendencia területi sajátosságainak leírásában az $u$-s lejegyzésü alakok nem használhatók fel.

A $v$ graféma esetében hasonló problémával szembesülünk, az olyan adatokban ugyanis, mint pl. 1298: Kvzepberech (HA. 1: 93), 1295: Vlued (Gy. 2: 304), 1270/272: Vluespotok (HA. 1: 28), 1301/1373: vrmin (HA. 4: 49), [1230]/231: Tvl (HA. 1: 41), 1339: Vrs (KMHsz. 1: 212) az ü-s és $\ddot{o}$-s olvasat egyaránt feltételezhető.

Az $\ddot{u}$ és $\ddot{o}$ hangok elkülönítését az $\ddot{o}$ hang $o$ betüvel való jelölése teszi majd csak lehetővé, amire legkorábban a 13. századból ${ }^{5}$ találunk példát: 1211: Nomuolou [nöm ßaló] (KNIEZSA 1952: 31; KOROMPAY 2003: 288), 1214: Ykortou (BÁRCZI 1958: 46), 1252: Kortuelyes (KNIEZSA 1952: 52), 1274: Gokyvolg (HA. 1: 60), 1275/1281: Zederiesuolg (BÁRCZI 1958: 46), 1276: Vatavolge (KNIEZSA

${ }^{4}$ BÁRCZI szerint még a mainál is ritkább volt, sőt egyes nyelvjárásokból hiányzott is (1975: 130, E. ABAFFY 2003: 124).

${ }^{5}$ Az 1113-as zobori oklevél Copusde [Köpösd] adatában (FEJÉRPATAKY 1892: 56) KNIEZSA kezdetben az $o$-t az $\ddot{o}$ hang jelének tartotta (1949: 10), később azonban ezt az adat koraisága miatt elvetette, s úgy vélekedett, hogy az oklevél letisztázója a $v$-t valószínúleg $o$-nak olvasta (1952: 52, vö. még BÁRCZI 1958: 46). 
1952: 53), 1277: Holges (KNIEZSA 1952: 53), 1281: Zedriesvolg (HA. 4: 72), 1298: Saulfolde (KMHsz. 1: 236), 1310: Jakusfolde (KNIEZSA 1952: 53), 1329: Foldwar (KNIEZSA 1952: 53), 1341: Busdarwolge, Busdarvolge (KNIEZSA 1952: 53), 1347: Halalwolg, Jarovolg, 1352: Foldfolua, 1358: Bonchwolge (KNIEZSA 1952: 53). Nem véletlen, hogy éppen azokban az elemekben találunk legkorábban ilyen jelölést, ahol az $l$ elötti $\ddot{e}>\ddot{o}$ labializáció következtében jelenik meg az $\ddot{o}$ hang. KNIEZSA az $\ddot{o}$ hang első előfordulásáról általában véve is azt állapítja meg, hogy az „kezdetben föleg $l$ elött szerepel, ami arra vall, hogy az $e$ elöször $l$ előtt labializálódott” (1952: 52). Mivel azonban a néhány tucatnyi ilyen jelölésű adat mennyisége eltörpül az $u$-s jelölés gyakorisága mellett, ezekre szintén nem alapozhatunk területi jellegü vizsgálatot.

Valószínűleg az $\ddot{o}$ fonémának a magyar hangrendszerbe való beépülése, majd egyre gyakoribbá válása hívta életre a kancelláriai helyesírás harmadik korszakában az $\ddot{O}$ hang jeleként az olyan grafémakombinációk használatát, mint például az ew, eu, ev, eo (vö. KNIEZSA 1952: 39, 52, 1959: 7; KoCSIS 2014: 3). Az eu vagy az ew betúkapcsolatok használata KNIEZSA szerint azzal magyarázható, hogy az ő a korábbi eü diftongusból alakult, aminek eu, ew volt a jelölése. Nem zárható ki ugyanakkor, hogy az $\ddot{o}$ hangot már eredendően is jelölték betükapcsolattal. A kancelláriai helyesírás harmadik korszakában, a 13. század második felétől kezdve aztán a hoszszú $o ̋$ jelét a rövid $O$ hangra is alkalmazták (1952: 52, 1959: 7). KNIEZSA úgy véli, hogy egyfelől éppen ez jelzi azt, hogy a régi eü diftongus helyébe a hosszú ő lépett.

Az ew, eu, ev, eo azonban továbbra sem jelentik az $\ddot{o}$ hang egyértelmú jelölését, hiszen azok $\ddot{e} \ddot{u} \sim \ddot{o} \sim \ddot{u}$ (1313: Gyubarthfewldy, KMHsz. 1: 113; 1346: Ewrs, KMHsz. 1: 212; 1332: Kysueulg, HA. 3: 53; 1329: Beulch, KMHsz. 1: 65; [1335]/336: Pop-

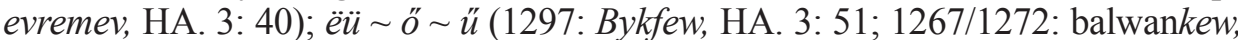
HA. 1: 23; 1317/1323: Almasweug, HA. 1: 39; 1261/1271: Kysgeur, KMHsz. 1: 156; 1294/1375: Chyglafev, HA. 4: 44); illetve $\ddot{e} 0 \ddot{o} \sim \ddot{o} \sim$ (1257/1284: Sasweolgy, KNIEZSA 1952: 53; 1323: Feoldwar, KNIEZSA 1952: 53; 1320: Kokolleo, Gy. 3: 556) hangként egyaránt olvashatók (KOROMPAY 2003: 289). Ezek a betükapcsolatok KNIEZSA szerint szinte kivétel nélkül $l$ elött jelentkeznek, leggyakrabban a föld és a völgy szavakban (vö. KNIEZSA 1952: 53-54), de a fenti adatok között jó néhány más példát (pl. 1346: Ewrs, KMHsz. 1: 212; 1297: Bykfew, HA. 3: 51) is találunk. Az azonban kétségkívül szembetünő, hogy mind az $o$-s, mind a betúkapcsolatos jelölés esetében az $\ddot{o}$ hangérték $l$ elötti pozícióban a leggyakoribb. Ez pedig esetleg azt sejteti, hogy e jelölésmódok kialakításában az $l$ előtt bekövetkező $\ddot{e}>\ddot{o}$ labializációnak lehetett leginkább motiváló ereje (KNIEZSA 1952: 52).

Az $\ddot{o}$ hang jelölésében a 15. század jelentett fordulópontot, amikor az egy betü - egy hang elvét követve a kódexek helyesírásában bizonyos források mellékjeles betüt kezdtek alkalmazni a fonéma lejegyzésére (pl. 1495 e.: zomeinec, koferufege, edos; TESz.; KNIEZSA 1959: 11; KOROMPAY 2003: 296; 2018: 86; KOCSIS 2014: 3). Husz János elvének alkalmazása azonban még ebben az időszakban sem teremtette meg az egységességet, mivel a scriptorok a betükapcsolatos és a mellékjeles írásmódot vegyítve használták (pl. 1538: Kezeneteŭmet; RML. 1: 390; KNIEZSA 1952: 124, 125, 1959: 14; KOROMPAY 2003: 297). Ennek ellenére „a mellékjeles helyesírás lehetőséget teremt arra, hogy a magyar fonémarendszer 
szembenállásai úgyszólván tökéletesen megjelenjenek" (KOROMPAY 2003: 296), mivel azokat a hangokat is képes volt megkülönböztetni, amelyekre a kancelláriai helyesírásnak nem volt külön jele (KNIEZSA 1959: 11).

Azt mondhatjuk tehát, hogy az $\ddot{u}$ és $\ddot{o}$ hangokat jelölő betük egyértelmü elkülönítésére, nagy számban való vizsgálatára és ezáltal a nyíltabbá válás bekövetkeztének minden kétséget kizáró igazolására az adatokban leghamarabb csak a 15. századi nem okleveles forrásokban nyílik lehetőségünk. BÁRCZI GÉZA is úgy nyilatkozik, hogy ,az $u$-s írásmód túlnyomó egészen a XIV. század végéig, sőt átnyúlik a XV. századba is" (1958: 46).

Ebben az összefüggésben pedig különösen elgondolkodtató $\mathrm{s}$ az itt idézett gondolatával nehezen összeegyeztethető az $\ddot{u}>\ddot{o}$ nyíltabbá válás kronológiai sajátosságairól mondott véleménye, mely szerint annak kezdete talán a 12. századra megy vissza (BÁRCZI 1958: 46). Az ezt igazoló 12. század eleji példáról (1113: copusde) azonban ő maga is úgy vélekedik, hogy az talán íráshiba, de az általa „nem kifogásolható példák” (1211: Nomuolou, 1214: Ykortou, 1275/1281: Zederiesuolg) kapcsán is joggal vetődhet fel a kérdés, hogy azok valóban a nyíltabbá válás következtében jöttek-e létre. Különösen a völgy lexéma esetében indokolatlan ennek a változási iránynak a feltételezése, egy egykori *vülgy forma meglétét ugyanis sem az etimológiai ismereteink (vö. TESz.), sem az egykori adatok nem igazolják. Mindössze néhány olyan adatunk van ugyanis a korai ómagyar korból, amelyek esetében az $\ddot{u}$-s és az $\ddot{o}$-s olvasat is feltételezhető; ezek a következök: 1297: Hatarwlg (HA. 3: 52), +1263/+1264: Zarazwlg, Zekereswlg (HA. 1: 30), 1331: Zekereswlgefeu (HA. 1: 30), 1327: Hangunuulge (Gy. 2: 504), 1325/1380/1470: Kalachnewlgye (HA. 4: 76). Megbízhatóbb fogódzót jelent viszont a változás lezajlásának kronológiai sajátosságait illetően BÁRCZInak az a megjegyzése, hogy mivel az $u$-s írásmód jóval tovább kitart, mint az $u>o$ esetében, ezért az $\ddot{u}>\ddot{o}$ nyíltabbá válás valószínűleg a változási tendencia leglassabban ható folyamata lehetett, ezt jelezhetik a 16. századi kódexekben szereplö gyüngy, gyükér formák is (BÁRCZI 1958: 46, 1975: 130).

5. Az $\ddot{o}$-zés legerőteljesebb válfaja, a független $\ddot{o}$-zés ma a Dél-Dunántúlon, a Dél-Alföldön, Szenc környékén és Erdélyben, Udvarhelyszéken jellemző. Ezeken a területeken bizonyos egyszótagú és vegyes hangrendủ szavaink kivételével $\ddot{o}$ hang áll a más nyelvjárásokban szereplő ë helyén (HORGER 1933: 105; KÁLMÁN 1966: 38-39; IMRE 1968: 193, 196, 1971: 203; FODOR 2001: 336-337). A Szenc környéki és az udvarhelyszéki adatokat az ö-zés gócpontjának kijelölésekor nem szükséges figyelembe vennünk, ezeknek a területeknek a nyelvjárási sajátosságai ugyanis korábbi betelepülés eredményeképpen magyarázhatók (SZABÓ 1996; JUHÁSZ 1999: 86, 2016: 265, 2018: 323).

Az $\ddot{o}$-zés gócpontjának meghatározásakor bizonyos szempontból valóban kézenfekvő kiindulási pont az, hogy a jelenség terjedésének magvát a legerőteljesebb $\ddot{o}$-zést mutató területekhez kössük. A nyelvjárási jelenségek egyes fázisai ugyanis gyakran hullámszerüen terjednek, ami azzal jár, hogy „,a jelenségnek rendszerint időben legkorábban keletkezett foka hatol a legmesszebbre, a további fázisok területi elterjedési köre pedig egyre kisebb és kisebb" (BENKÖ 1957: 22). 
Ebből pedig az is következik, hogy a terjedés gócpontjának a legnagyobb valószínűséggel az egyes fázisok eredményeit egyaránt tükröző terület tekinthető.

A jelenkori független $\ddot{o}$-zés és a korai ómagyar kori $\ddot{u}$-zés kapcsolatának vizsgálatához A magyar nyelvjárások atlaszának következő, független ö-zést mutató kutatópontjainak adatait használtam fel: Pat (B33) (Zala m.); Szenta (B35), Mesztegnyő (D12), Somogyacsa (D15), Lábod (D21), Kisasszond (D22), Kaposgyarmat (D25), Gölle (D27), Péterhida (D28), Kálmáncsa (D29) (Somogy m.); Dunavecse (F3), Dunapataj (F6), Szeremle (F22), Érsekcsanád (F23), Izsák (K1) (Bács-Kiskun m.); Gerjen (F10), Alsónyék (F15) (Tolna m.); Okorág (G3) (Baranya m.); Algyő (K12), Földeák (N8) (Csongrád m.) (vö. IMRE 1971: 207). ${ }^{6}$ A vizsgálatba több mint 50 olyan lexémát vontam be, amelyeknek ezeken a kutatópontokon adatolható $\ddot{o}$-zö formája a más nyelvjárásokban tapasztalható ë-zéssel szemben. Az így kapott több mint ezer $\ddot{o}$-ző adat mellett olyan elemeket is vizsgáltam, amelyek máshol nem $\ddot{e}$-ző alakúak, és a vizsgált területen nem $\ddot{o}$-zö formájúak (1. a pünkösd, idö, kövek megfelelö nyelvjárási formáit). Úgy gondoltam ugyanis, hogy az $\ddot{o}$-zés kialakulása szempontjából ezeknek az elemeknek a vizsgálata is fontos hozadékokkal járhat.

6. Az ezeken a területeken adatolható $\ddot{o}$-ző formák egy része feltételezhetően korai $i$-ző alakokra vezethető vissza, tehát az $i>\ddot{u}>\ddot{o}$ változás eredményeképpen is keletkezhetett. Az ebbe a kategóriába sorolható adatok azonban azért nem szolgálhatnak bizonyítékként arra, hogy a legerősebb $\ddot{o}$-ző tendenciát mutató területek az $i$ $>\ddot{u}$ változás gócpontjaiként is felfoghatók, mert ezek a formák - amint arról fentebb már szó esett - akár az $i>\ddot{e}>\ddot{o}$ változások eredményeként is kialakulhattak.

KIS TAMÁS ugyanakkor LAZICZIUSszal egyetértve úgy gondolja, hogy a hangváltozások fokozatosságáról vallott újgrammatikus elképzelések, amelyek bizonyos mértékig a magyar hangtörténeti szakirodalomban mind a mai napig továbbélnek, nem tarthatók, mert fonológiai okok miatt ,,a hangváltozások a nyelvben mindíg és kivétel nélkül ugrásszerüek" (LAZICZIUS 1932: 84; KIS 2014: 103, 2019: 61). Ilyen módon pedig jelen esetben akár az $i>\ddot{o}$ változás ${ }^{7}$ is elképzelhetö közbülső fokozatok feltételezése nélkül. Az erősen labializáló területeken ugyanakkor bizonyos nevek esetében akár annak is tanúi lehetünk, hogy a szláv nyelvi $i$-ző alak $\ddot{u}$-ző vagy $\ddot{o}$-ző formában kerül a magyar nyelvbe, pl. szlk. Ladice > 1253: Leuduch, Leduch (TÓтн 2001: 212). Az idegen elemek magyar nyelvbe kerülése során azok hangtani adaptációja még inkább jelzi a hangváltozások ugrásszerü voltát, vagyis a hangsormintá(k)hoz (a fogalomhoz 1. SZENDE 1978: 254; KASSAI 2000: 113, 115; FEHÉR 2009: 90) való igazodást. Ezeknek a fokozatoknak (vagyis az ü-zö és az ë-ző formáknak) a kimutatása ráadásul helyesírás-történeti okok (az $\ddot{u}$ és az $\ddot{o}$, illetve

${ }^{6} \mathrm{Az} \mathrm{MNyA}$ adatait digitális formában BÁRTH M. JÁNOS szívességének köszönhetem.

${ }^{7}$ Hozzá kell tennünk ugyanakkor, hogy amikor LAZICZIUS a hangváltozások ugrásszerüségéről beszél, az alatt nem a több fonémányi, hanem csak a fonémányi ugrásokat érti, azt hangsúlyozva, hogy a hangváltozások nem apró, fonetikai módosulásokon keresztül következnek be (1932: 84, 1934: 351-358). 
az i és az ë hangok sokáig tartó azonos jelölése) miatt éppen olyan bizonytalan, mint sok esetben a korai i-ző formák igazolása. ${ }^{8}$

Elképzelhető például, hogy a szóvég felöl induló $i>\ddot{u}$ labializáció, majd ezt követően az $\ddot{u}>\ddot{o}$ nyíltabbá válás következtében jöttek létre a vizsgált kutatópontokon az olyan $\ddot{o}$-ző formák, mint például az ősi eredetü szem nyelvjárási szöm formái (szöm, B35, D12, D15, D21, D25, D27, D28, D29, F3, F6, F15, F22, F23, K1, K12, N8; szöm, B33, D22, D28, F10; buzaszöm, D22, G3; MNyA. 8) (1. ehhez E. ABAFFY 2003: 326). Az uráli alapalak a megfelelö uráli nyelvbeli adatok alapján *ślmä lehetett (TESz.; UEW. 479; MSzFE. 3: 579; EWUng.). Ilyen módon tehát az $i>\ddot{u}>\ddot{o}$ (pl. 1237/1325: Scim, Ok1Sz. > 1195 k.: zumtuchel, TESz. > 1495 e.: 3omeinec, TESz.), az $i>\ddot{e}>\ddot{o}$ (pl. 1237/1325: Scim, Ok1Sz. $>1067$ k./1267: Zemy, TESz. > 1495 e.: zomeinec, TESz.) vagy akár az ugrásszerü $i>\ddot{o}$ változási mód is legalább ilyen valószínüséggel feltételezhetö.

Hasonlóan vélekedhetünk az ótörök eredetü gyeplő nyelvjárási 0 -ző formáinak (gyöplü, B33, B35, D22; gyöprü, D21, D28, D29; gyöplüszár, D22; gyöprü, D28; gyöplü, K12, N8; gyöplüszár, K12; MNyA. 172) a kialakulásáról is. A ma-

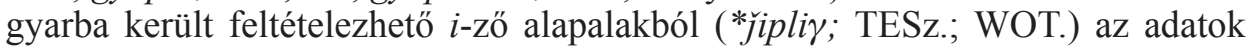
alapján az $i>\ddot{u}>\ddot{o}$ (pl. 1494-5: gywplw > 1548: gyöply $\ddot{u}$, TESz.) vagy $i>\ddot{e}>\ddot{o}$ (pl. 1395 k.: keplow [o: geplow], 1405 k.: geplw> 1587: geoplwth, TESz.) folyamat egyaránt elképzelhető.

7. Az $i>\ddot{u}$ változás gócpontjának a mai független $\ddot{o}$-ző területekkel való azonosítása emellett azért is vitatható, mert a labializáció által létrejött alakok természetesen nem minden esetben alakulnak tovább nyíltabbá válással: azaz az $i>$ $\ddot{u}$ labializáció nem $\ddot{o}$-ző területeken is bőven eredményezhetett labiális formákat.

Így például a (szóvégi labiális magánhangzó hatására bekövetkező) labializációval alakult pünkösd vagy idö lexémák első szótagi ü-ző formái (üdö, B33, B35, D12, D15, D21, D22, D28, üdö 944; pünközsdi, B33, B35, D12, D15, D16, D21, D22, D25, D27, D28, D29, F22, F23, F3, F6, K1, K10, K12, N8, MNyA. 1108) mellett nem adatolhatunk nyíltabb, ö-ző formákat. A nyíltabbá válás a nyelvterület más részein sem mutatható ki a pünkösd esetében (vö. ÚMTsz.; MNyA.), ahogyan az idő lexémának is mindössze egy moldvai, szabófalvi ödö adata mutatja ezt a változást (ÚMTsz. 2: 1057).

A $\beta$ vagy $v$ hang $^{9}$ hatásával, annak kiesésével vagy vokalizálódásával, illetve a szótári forma labiális magánhangzójának (1. pl. 1009/?1235/1350/1404: Kwarok, 1067 k./1267: Kuurew; TESz.) hatásával magyarázható labializáció

${ }^{8}$ A nyugati ótörök eredetủ tengely lexéma ö-ző alakjainak (1587: Töngö, 1590: Tengóly, TESz.; tengöj, F3, tęngö, D27, MNyA. 156) keletkezése kapcsán például elbizonytalanító körülmény, hogy a TESz. és a WOT. eltérően foglal állást abban a tekintetben, hogy a magyarba került

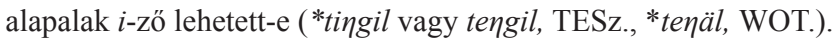

${ }^{9}$ KIS TAMÁS az ómagyar bilabiális $\beta$-ről írott munkájában amellett érvel, hogy a változás a $\beta$ feltevése nélkül is jól magyarázható, a $\beta$ és a $v$ hang ugyanúgy alkalmas ugyanis a vokalizálódásra, ami ,nem a képzési helyből, hanem az adott hang szonoráns approximáns voltából következik, a labiodentális approximáns $v[\ldots]$ ugyanúgy vokalizálódhat, mint a bilabiális approximáns $\beta$, viszont nem lesz magánhangzó se a bilabiális, se a labiodentális zöngés réshangból, ha az frikatíva” (2019: 58). 
eredményeképpen létrejövő kövek lexémának ugyancsak nem jellemző az $\ddot{o}$-ző formája a vizsgált területen. Az adott kutatópontokon ugyanis többnyire a küvek és föként küjek alakok különböző hangszínrealizációi jelennek meg: küjèk (B35), küjek (D28), küiek (D27), küję (D12, D15, D28), kü̈ek, (D29), küjẹk (B33), küjek (D21, D25, G3, D22, D27, D29, D28), küjjęk(B33, B35), küvek (F3, F6, F10, F15, F22, F23, K1, K12, N8) [küek] (D22). Mindössze két kutatóponton adatolható az atlasz által neológként megjelölt [kövek] alak (D27, D28). Hozzá kell tennünk ugyanakkor egyrészt azt, hogy ahogyan a fenti példák mutatják, valójában mégis labiális formákat (ü-s alakokat) adatolhatunk a területen, ami a labializációs tendenciák egymást erősítő hatása miatt lényeges körülmény. Másrészt a köznyelvi $\ddot{o}$ : nyelvjárási $\ddot{u}$ szembenállás (amit tehát a kövek esetében látunk) IMRE SAMU megfigyelései szerint a $v$ - tövủ szavak esetében általános sajátosság (1. még jövök, tövestül, lövök, 1971: 174).

8. Más esetekben az ezeken a területeken megjelenő $\ddot{o}$-ző forma egyértelmúen nem nyíltabbá válással, hanem az $\ddot{e}>\ddot{o}$ labializációval keletkezett. A cseresznye lexéma ö-zö alakjainak (pl. 1583-4: chröfnye fa, ${ }^{10}$ TESz.; csörösnye cserös(z)nye cserösnye, B33, D22; csörösnye, B35; cserösnye, D12, D22, D28, F23; cserösnye, D15; cserösnye, D15, D25, D27, D28, D29; F22, F23, F15, csörösnye, D21, D29, G3; <cserösnye> D21, G3; cserösznye, K12, N8, F3, F6, F10, K1, [csörösnye] D28, < cserösnye > F22, cserösnye, F23, MNyA. 95) kialakulása például a szláv nyelvi megfelelők (szb.-e. szl. črěšbnja, szb.-hv. trëšnja, kaj. čréšnja, szlovén črẹšnja, szlk. čerešňa, TESz., KNIEZSA 1955: 129) és az ezekből, valamint a korai adatokból kikövetkeztethető magyar nyelvbeli elsődleges (cseresnya, TESz.; cseresnye, KNIEZSA 1955: 130) alak alapján nem a nyíltabbá válással létrejövő, hanem az ö-zés egy másik keletkezéstörténeti kategóriájába, az $\ddot{e}>\ddot{o}$ labializáció esetei közé sorolható.

A szintén szláv eredetü gerendely (vö. blg. N. греде́л, szb.-hv. grédelj, szln. grédelj, szlk. hriadel'; TESz.; KNIEZSA 1955: 192) ö-ző formái (1590: gerendölyt, OklSz., göröndöj, D22, göröndôj, N8, MNyA. 124) a magyarba került ősszláv * grędeljb alak alapján ugyancsak ebbe a kategóriába, vagyis az $\ddot{e}>\ddot{o}$ labializáció esetei közé sorolhatók.

A német eredetủ zsindely hangsúlytalan szótagja a megfelelö etimonok (pl. kfn. schindel, ném. Schindel, baj.-osztr. šindl, szász E. šęndal, szlovákiai ném. N. šendl) alapján bizonyosan ë-ző volt az ómagyar korban (vö. még 1371: Sendel, 1405 k.: Sendel, 1500: Sindelsegh (TESz.). A 16. században feltünő ö-ző forma s a vizsgált területen a jelenkorban is élö ö-ző alakok (1553: sindöl, TESz., sindöl, D15, D27, F3, F6, F15, F23; sindöj, D27, zsindöj, F15, F23; zsindöl, F6, F15, F22, $\mathrm{K} 1$; MNyA. 202) tehát ugyancsak az $\ddot{e}>\ddot{o}$ labializáció eredményei lehetnek.

A korai $i$-ző adatok hiánya miatt nagy valószínüséggel szintén ebbe a keletkezéstörténeti kategóriába sorolhatók bizonyos származékszavak labiális formái,

${ }^{10}$ A labializáció koraiságának igazolása érdekében a jelenkori nyelvjárási adatok előtt feltüntetem az első labiális történeti adatokat, ami ugyanakkor nem jelenti azt, hogy ezek a történeti adatok minden esetben az adott területhez köthetők lennének. 
vagyis az $i>\ddot{u}$ változástól teljesen független lehet például az alábbi lexémák $\ddot{o}$-ző változatainak kialakulása: keserü (1495k.: koferufege, 1533: Ko̊fero̊, Ko̊fferö, 1598: kôsserüt, TESz.; köserëü, B33, B35, D12, D22, köserü, D12, köserü, D21, D22, D25, D28, D29, köserü, D21, D29, köserü, D28, D29, MNyA. 696); menyét (1533: Mơniet, mơnet, TESz.; mönyét, D12, D15, D21, D27, D29, F3, F6, F10, F15, F22, F23, G3, K12, N8, mönyét, D12, mönyétt, D22, mönyétt, D27, G3, mönyệtt, D28, mönyént, D29, G3, mönyét, G3, mönétke, K1, mönyétasszon, B35, D21, D29, mönyétasszon, B33, mönyétasszo, D21, D27, G3, mönyéttasszo, D22, mönyęitasszony, D22, mönyéitasszony, D25, mönyéntasszo, D29, mönyéntasszon, D29, G3, MNyA. 620); lepedö (1506: lepơdo̊ben, 1508: lepo̊dec, 1553: löpödökböl, TESz.; 1544: lepödöket, Ok1Sz.; lepödö, D15, D21, D29, F6, G3, lepödö, B33, B35, lepödồ, B33, lepödò, B35, D28, lepödö, B35, D12, D28, lepödő, D12, lepödö lepödö̈, D22, lepödöü, D27, lepödő, D29, lepödö, F10, lepödő, G3, MNyA. 218); édes (1495 e.: edos, TESz.; édös, B33, B35, D15, D21, D22, D28, F3, F6, F10, F22, F23, G3, K1, K12, N8, édöss, D12, éidös, D22, D25, eёdös, D27, ếiös, D27, édös, D29, 'édös, F15, édös, K12, MNyA. 694), énekel (1495 e.: enoclonec, TESz., énököl, B33, B35, D28, éneköl, B35, D28, F3, F6, F10, F15, F22, F23, K1, K12, N8, éinęöl, D22, éinekồl, D22, ęineköl, D22, énëköl, D28, inököl, D28, ünökö̀, D28, énekọl, F23, MNyA. 879); egyenes (1495 e.: igenos, 1532: eǵenós, TESz.; igyenös, B33, D12, D15, D21, igyenyös, B33, igenyös, B35, D28, F3, F10, F15, F22, K1, K12, N8, igyenös, B35, D21, D22, D25, D27, D28, D29, F10, F15, F22, F23, F6, G3, K12, igyenös, D21, D22, ëgyenös, D28, K12, ëgyenös, D28, MNyA. 708).

9. Arra is fel kell hívnunk ugyanakkor a figyelmet, hogy a legerősebben $\ddot{o}$-ző tendenciát mutató területek $\ddot{o}$-ző formái gyakran csak a 18-20. században bukkannak fel az írott forrásokban. Ezek alapján a kései adatok alapján pedig ómagyar kori nyelvjárástörténeti következtetéseket aligha vonhatunk le.

Nem ritkán az illabiális forma is csak a 16. században vagy még később adatolható először, pl. felhérc (1547: felhercztöl, 1780: förhétzszegnek, TESz.), lebernyeg (1590: Lepenyeg, TESz.; lebörnyeg, ÚMTsz.), henger (1784: henger, 1796: höngöriteni, 1833: Höngör, TESz.), cicerél (1829: Cziczerélem, TESz.; cicörél, ÚMTsz.), derelye (1786: derelye, 1888: dörölye-fülü, TESz.).

Előfordul továbbá az is, hogy az ómagyar korban megjelenő illabiális formák után is csak jóval később találunk ö-ző adatokat, pl. meggy (1338: Meggesmaalberchy, 1834: mögy, TESz.), cinege (1346: Cynege, TESz.; 1893: cinöge, MTsz.), este (1372 u./1448 k.: eftue, 1794: östve, TESz.), derék (1307: derekas, 1840: dorek, TESz.), lencse (1325: Lenche, 1893: löncse, MTsz.), gereben (1294: Gerebenes, 1863: göröbenbe, TESz.), fergettyü (1515: Fergethew, 1809: Fergötyǘ, 1831: Förgettyü, TESz.), perje (1411: Keserewperye, 1892: Pörgye fü, TESz.), pendely (1431: Pentel, 1670-704: Péntölöm, TESz.).

10. A fenti példákon keresztül azt a kérdést próbáltam meg körüljárni, hogy vajon a jelenkori független $\ddot{o}$-zést mutató területek $\ddot{o}$-ző formáinak keletkezéstörténete igazolhatja-e azt az elképzelést, mely szerint az $\ddot{u}>\ddot{o}$ nyíltabbá válásnak 
az $\ddot{o}$-zés kialakulásában olyan nagy szerepe volt, hogy esetleg a korábbi $\ddot{u}$-ző nyelvjárás alakulhatott át $\ddot{o}$-zővé. Az általam bemutatott példák reményem szerint felhívják a figyelmet azokra a módszertani buktatókra, illetve nehézségekre, amelyek megnehezítik, sőt akár meg is akadályozzák az említett feltevés igazolását. A legnagyobb korlátot megítélésem szerint az jelenti, hogy még azoknak az elemeknek az esetében is lehetetlen bizonyítani az $i>\ddot{u}>\ddot{o}$ változási sor lezajlását, amelyek kapcsán az eredeti $i$-ző alak megléte igazolható vagy legalább feltételezhető.

A jelenkori nyelvjárási adatoknak a korai ómagyar korra való vonatkoztatása az itt bemutatottak mellett más akadályokba is ütközik. A nyelvjárási viszonyokat bizonyos településtörténeti változások ugyanis nagymértékben átrendezhetik. Ezt a körülményt különösen fontos szem előtt tartanunk akkor, amikor az összevető vizsgálat egyfelől ilyen nagy időtávlatot kíván egybefogni, másfelől pedig éppen azokra a területekre vonatkozik, amelyek esetében a települési állandóság és ezzel együtt a demográfiai folytonosság (például a török hódoltság, majd az azt követő telepítések hatására) kevésbé volt jellemző (vö. BENKŐ 1957: 45; JUHÁSZ 2018: 319). Óvatosságunk e tekintetben még azzal együtt is indokolt lehet, ha figyelembe vesszük JUHÁsz DEZSŐ megállapítását, amely szerint az ö-ző területek közül ,a dél-dunántúli az, amely a török hódoltság pusztításait követően épebben megőrizte középkori nyelvföldrajzi szerkezetét" (2018: 324).

Kulcsszók: nyelvjárástörténet, jelenkori nyelvjárási adatok, forrásérték, labializáció.

\section{Hivatkozott irodalom}

E. ABAFFy ERZSÉBET 2003. Hangtörténet. In: KisS JenÖ - PUSZTAI FerENC szerk., Magyar nyelvtörténet. Osiris Kiadó, Budapest. 106-128, 301-351.

BÁBA BARBARA 2019. Az $i \sim u ̈$ szembenállás területi és kronológiai sajátosságai a korai ómagyar korban. In: ForgáCS TAMÁs - NÉMETH MiKLós - SinKOVICS BALÁzS szerk., A nyelvtörténeti kutatások újabb eredményei X. Szegedi Tudományegyetem, Magyar Nyelvészeti Tanszék, Szeged. 7-18.

BÁRCZI GÉZA 1958. Magyar hangtörténet. Második, bővített kiadás. Tankönyvkiadó, Budapest.

BÁRCZI GÉZA 1964. A nyelvjáráskutatás újabb eredményei és feladatai. Magyar Nyelv 60: 3-16.

BÁRCZI GÉZA 1967/2002. Hangtörténet. In: BÁRCZI GÉZA - BENKÖ LORÁND - BERRÁR Jolán szerk., A magyar nyelv története. Nemzeti Tankönyvkiadó, Budapest. 95-180.

BÁRCZI GÉZA 1975. A magyar nyelv életrajza. Harmadik kiadás. Gondolat Kiadó, Budapest. BENKÖ LORÁND 1957. Magyar nyelvjárástörténet. Tankönyvkiadó, Budapest.

BENKÖ LORÁND 1967. Nyelvtörténet és a mai nyelv. Általános Nyelvészeti Tanulmányok 5: 41-67.

BENKŐ LORÁND 1967/2003. A nyelvföldrajz történeti tanulságai. (Akadémiai székfoglaló előadás). In: BENKÖ LORÁND, Nyelv és tudomány, anyanyelv és nyelvtudomány. Válogatás Benkö Loránd tanulmányaiból 1-3. ELTE BTK Magyar Nyelvtörténeti, Szociolingvisztikai, Dialektológiai Tanszék, Budapest. 2: 156-178. 
BENKÖ LORÁND 1990. Az élő nyelv területisége és szociolingvisztikája In: SzABÓ GÉZA szerk., II. dialektológiai szimpozion. MTA Veszprémi Akadémiai Bizottsága, Veszprém. 9-22.

ByNON, THEODORA 1997. Történeti nyelvészet. Osiris Kiadó, Budapest.

ERDÉLYI LAJOS 1905. Nyelvjárásaink ügye és teendőink. Magyar Nyelv 1: 291-337.

EWUng. = Etymologisches Wörterbuch des Ungarischen 1-2. Hrsg. BENKÖ, LORÁND. Akadémiai Kiadó, Budapest, 1993-1995.

FEHÉR KRISZTINA 2009. Dialektális hangjelenségek és az ún. zöngésségi hasonulások. In: É. KISS KATALIN - HEGEDÜS ATTILA szerk., Nyelvelmélet és dialektológia. PPKE BTK Elméleti Nyelvészeti Tanszék - Magyar Nyelvészeti Tanszék, Piliscsaba. 85-96.

FEJÉRPATAKY LÁSZLÓ 1892. Kálmán király oklevelei. Magyar Tudományos Akadémia, Budapest.

FODOR KATALIN 2001. A nyelvjárási hangtani jelenségek. In: KISS JENŐ szerk., Magyar dialektológia. Osiris Kiadó, Budapest. 325-350.

Gy. = GYÖRFFY GYÖRGY, Az Árpád-kori Magyarország történeti földrajza 1-4. Akadémiai Kiadó, Budapest, 1963-1998.

HA. 1-4. = HOFFMANN ISTVÁN - RÁCZ ANITA - TÓTH VALÉRIA, Helynévtörténeti adatok a korai ómagyar korból. 1. Abaúj-Csongrád vármegye. 2. Doboka-Győr vármegye. 3. Heves-Küküllö vármegye. 4. Liptó-Pilis vármegye. A Magyar Névarchívum Kiadványai 1., 3., 25., 43. Debreceni Egyetemi Kiadó, Debrecen, 1997-2017.

Horger ANTAL 1933. A magyar nyelvjárások ö-zése. Népünk és Nyelvünk 5: 101-107.

IMRE SAMU 1968. Az ö-zés típusai nyelvjárásainkban. Magyar Nyelv 64: 192-197.

IMRE SAMU 1971. Szinkrónia és diakrónia a magyar nyelvatlasz anyagában. Magyar Nyelv 67: 134-144.

JUHÁSZ DEZSÖ 1997. A nyelvtörténet a magyar dialektológiában. Magyar Nyelvjárások 34: 43-50.

JUHÁSZ DEZSÖ 1999. A történeti nyelvtan néhány kérdése a nyelvföldrajz szemszögéböl. In: BÜKY LÁSZLÓ - FORGÁCS TAMÁS szerk., A nyelvtörténeti kutatások újabb eredményei I. Magyar és finnugor mondattörténet. 1998. szeptember 23-24. Szeged, JATE Magyar Nyelvészeti Tanszék. 81-90.

JUHÁSZ DEZSÖ 2002. A dialektológia hármas feladata és a nyelvföldrajz. In: SZABÓ GÉZA MOLNÁR ZOLTÁN - GUTTMANN MIKLÓs szerk., IV. dialektológiai szimpozion. BDF Magyar Nyelvészeti Tanszék, Szombathely. 149-153.

JuHÁSz DEZSŐ 2007. A nyelvföldrajz történeti tanulságai. Egy klasszikus tanulmány negyven év távlatából. In: GUTTMANN MiKLós - MoLNÁR ZoLTÁN szerk., $V$. dialektológiai szimpozion. BDF Magyar Nyelvészeti Tanszék, Szombathely. 133-138.

JuHÁSZ DEZSŐ 2016. A magyar nyelvjárástörténet néhány kérdése. Magyar Nyelv 112: 257-268. https://doi.org/10.18349/magyarnyelv.2016.3.257

JuHÁSZ DEZSÖ 2018. A nyelvjárások történetéböl. In: KISS JENÖ - PUSZTAI FERENC szerk., A magyar nyelvtörténet kézikönyve. A Magyar Nyelv Kézikönyvei 29. Tinta Könyvkiadó, Budapest. 314-349.

KASSAI ILONA 2000. Nyelvek és kultúrák érintkezésének tükröződése a magyar szótag szerkezetében. In: BORBÉLY ANNA szerk., Nyelvek és kultúrák érintkezése a Kárpátmedencében. A 10. élőnyelvi konferencia elöadásai. MTA Nyelvtudományi Intézet, Budapest. 113-119. 
KÁLMÁN BÉla 1966. Nyelvjárásaink. 6. kiadás. Nemzeti Tankönyvkiadó, Budapest. KIS TAMÁS 2014. Leíró hangtan és hangtörténet. Magyar Nyelvjárások 52: 89-124.

KIS TAMÁS 2019. Az ómagyar bilabiális $\beta$ kérdéséhez. A Debreceni Egyetem Magyar Nyelvtudományi Intézetének Kiadványai 93. Debreceni Egyetem Magyar Nyelvtudományi Intézet, Debrecen.

KISS JENÖ 1981. Nyelvjárási tanulmányok. A Magyar Nyelvtudományi Társaság Kiadványai 159. Magyar Nyelvtudományi Társaság, Budapest.

KISS JENÖ 2003. Általános kérdések. In: KISS JENÖ - PUSZTAI FERENC szerk., Magyar nyelvtörténet. Osiris Kiadó, Budapest. 11-68.

KMHsz. = Korai magyar helynévszótár 1-Abaúj-Csongrád vármegye. Szerk. HoffMANN IstvÁN. A Magyar Névarchívum Kiadványai 10. Debreceni Egyetem Magyar Nyelvtudományi Tanszék, Debrecen, 2005-.

KNIEZSA ISTVÁN 1949. A zobori apátság 1111. és 1113. évi oklevelei mint nyelvi (nyelvjárási) emlékek. Magyar Népnyelv 6: 1-52.

KNIEZSA ISTVÁN 1952. Helyesírásunk története a könyvnyomtatás koráig. Akadémiai Kiadó, Budapest.

KNIEZSA ISTVÁN 1955. A magyar nyelv szláv jövevényszavai 1/1-2. Akadémiai Kiadó, Budapest.

KNIEZSA IsTVÁN 1959. A magyar helyesírás története. Második, javított kiadás. Tankönyvkiadó, Budapest.

KOCSIS ZSUZSANNA 2014. Az $\ddot{O}$ hang jelölése és a fonéma gyakorisága közötti lehetséges összefüggések vizsgálata Svetkovics Katalin levelezésében. In: DRÁvUCZ FANNI HAINDRICH HElga ANNA - HORVÁTH KRISZTINA szerk., Doktoranduszok a nyelvtudomány útjain. Az ELTE BTK Nyelvtudományi Doktori Iskolája „,Félúton 9.” Konferenciájának kiadványa. ELTE BTK Nyelvtudományi Doktori Iskola, Budapest. 3-10.

KorOMPAY KLÁRA 2003. Helyesírás-történet. In: KISS JENÖ - PUSZTAI FERENC szerk., Magyar nyelvtörténet. Osiris Kiadó, Budapest. 281-300.

KOROMPAY KLÁRA 2018. Helyesírás-történet. In: KISS JENÖ - PUSZTAI FERENC szerk., A magyar nyelvtörténet kézikönyve. A Magyar Nyelv Kézikönyvei 29. Tinta Könyvkiadó, Budapest. 83-98.

LAZICZIUS GyUlA 1932. Bevezetés a fonológiába. A Magyar Nyelvtudományi Társaság Kiadványai 33. Magyar Nyelvtudományi Társaság, Budapest.

LAZICZIUS GyUlA 1934. Bevezetés a fonológiába. III. Történeti fonológia. Nyelvtudományi Közlemények 48: 349-381.

LAZICZIUS GyUlA 1936. A magyar nyelvjárások. Magyar Tudományos Akadémia, Budapest.

MNyA. = A magyar nyelvjárások atlasza 1-6. Szerk. DEME LÁSZLÓ-IMRE SAMU. Akadémiai Kiadó, Budapest, 1968-1977.

MSzFE. = A magyar szókészlet finnugor elemei 1-3. Főszerk. LAKÓ GYÖRGY. Akadémiai Kiadó, Budapest, 1967-1978.

MTsz. = SZINNYEI JÓZSEF, Magyar tájszótár 1-2. Hornyánszky, Budapest, 1893-1901. OklSz. = SZAMOTA IstvÁN - ZOLNAI GyULA, Magyar oklevél-szótár. Pótlék a Magyar Nyelvtörténeti Szótárhoz. Magyar Tudományos Akadémia, Budapest, 1902-1906. ÖHA. = VÉGH JÓzSEF, Örségi és hetési nyelvatlasz. Akadémiai Kiadó, Budapest, 1959. PÉTER LÁSzLÓ 1951. Az ö-zés kérdéséhez. Magyar Nyelvjárások 1: 118-135. 
RML. I. = Régi magyar levéltár I. Középkori leveleink(1514-ig). Szerk. HEGEDÜS ATTILAPAPP LAJOS. Tankönyvkiadó, Budapest, 1991.

SiLling IstVÁn 2007. Kupuszinai nyelvjárás és szótára. Loisir Kiadó, Budapest.

SZABÓ JÓZSEF 1996. Az $\ddot{o}$ hang eredete és az $\ddot{o}$-zés elterjedése a magyar nyelvjárásokban. In: R. Molnár EMMA szerk., Absztrakció és valóság. Békési Imre köszöntése. JGYTF Kiadó, Szeged. 295-301.

SzENDE TAMÁs 1978. Gyula Décsy: Sprachherkunftsforschung. Band I. Einleitung und Phonogenese/Paläophonetik. Wiesbaden, Otto Harrassowitz, 1977. [Ismertetés.] Nyelvtudományi Közlemények 80: 252-255.

TESz. = A magyar nyelv történeti-etimológiai szótára 1-3. Főszerk. BENKÖ LORÁND. Akadémiai Kiadó, Budapest, 1967-1976.

TÓTH VALÉRIA 2001. Az Árpád-kori Abaúj és Bars vármegye helyneveinek történetietimológiai szótára. A Magyar Névarchívum Kiadványai 4. Debreceni Egyetem Magyar Nyelvtudományi Tanszéke, Debrecen.

UEW. = Uralisches Etymologisches Wörterbuch 1-2. Hrsg. RÉDEI, KÁROLY. Harrassowitz, Wiesbaden - Akadémiai Kiadó, Budapest, 1986-1988.

ÚMTsz. = Új magyar tájszótár 1-5. Főszerk. B. LŐRINCZY ÉVA. Akadémiai Kiadó, Budapest, 1979-2010.

WOT. = RÓNA-TAS, ANDRÁS - BERTA, ÁRPÁD, West Old Turkic. Turkic loanwords in Hungarian 1-2. Turcologica 84. Harrassowitz Verlag, Wiesbaden, 2011.

\section{The source value of contemporary dialects in historical dialectology}

It is one of the basic tenets of historical dialectology that in contemporary dialects the different chronological phases of various phenomena may be found side by side. As a result, it is clear that contemporary dialects may represent an important source for research in historical dialectology. The assessment of contemporary data and the examination of their evidential value, however, entails certain methodological obstacles. Thus, for example, as a result of changes in phonological oppositions or due to settlement history or migration processes, the linguistic phenomena found in contemporary dialects may be used for the localization of certain early dialectal features only with limitations. In many ways, however, today's dialectal data may provide real guidance for certain observations in historical dialectology. To illustrate this, my paper introduces various phonological phenomena in the study of which contemporary dialectal data may provide an authentic source for historical dialectology. This is followed by the examination of a specific problem, namely the question of why relying on contemporary dialectal data related to the use of the sound $\ddot{o}$ (rather than the mid $\ddot{e}$ of other dialects) when establishing the center for the use of $\ddot{u}$ in the same contexts in the Old Hungarian era might be problematic.

Keywords: historical dialectology, contemporary dialectal data, source value, labialization.

BÁBA BARBARA

Debreceni Egyetem 